\title{
Post-crisis restructuring of trade and financial architecture: Asian and European perspectives
}

\author{
Matthias Helble $^{1} \cdot$ Margot Schüller $^{2}$
}

(C) Springer-Verlag GmbH Germany 2017

The global financial and economic crisis (GFEC) that started in 2007 triggered a global economic downturn, which was particularly marked in Europe as well as the United States. Asia weathered the economic shock relatively well, although the knock-on transmissions through trade and financial channels still caused a slowdown of export demand and economic growth in many countries within the region. The consequences of the GFEC are still felt today. Economic growth across the world remains weak and prospects uncertain, while the need for structural changes in the real economy and the financial sector has increased.

The first paper of this special issue consequently provides an analysis of the current growth challenges in the European Union as well as Japan. In his paper, Dreger (2017) argues that in Japan, the weak growth in total factor productivity is mainly responsible for the overall sluggish economic growth rate, and that loose monetary policy and fiscal stimulus packages have little effect. In the euro area, Dreger evidences weak capital deepening due to economic uncertainty and related weak investment. Finally, he argues that for both economies the aging population and high debt-to-GDP ratios leave little scope for further demand-driven policies. He concludes that only structural reforms could induce higher investment and secure long-term growth.

Beyond the structural issues of aging populations and high debt-to-GDP ratios, Asia and Europe are faced with another worrying trend. The forthcoming exit of the United Kingdom from the EU as well as the election of Donald Trump as the new US President are expressions of a rise in populist movements. These trends will undoubtedly have major consequences for the international trade and financial architecture in the near

Matthias Helble

mhelble@adbi.org

Margot Schüller

Schueller@giga-hamburg.de

1 Asian Development Bank Institute, Tokyo, Japan

2 German Institute of Global and Area Studies, Hamburg, Germany 
future. In the area of trade, the former international consensus view of attempting to promote further economic integration is now being called into question. On his first day as US President, Donald Trump announced the withdrawal of the US from the TransPacific Partnership (TPP). The TPP was previously recognized as a trade agreement that introduced new rules on important emerging issues in international trade, such as ecommerce. A similar fate befell the Trans-Atlantic Trade and Investment Partnership (TTIP) too. Despite the enormous potential to generate additional trade between the EU and the US, the TTIP failed to garner sufficient public support for it on either side of the Atlantic.

The next two contributions to this special issue give an outlook on the future of trade policy in the EU, as well as on the TPP. Bungenberg and Hazarika (2017) together study the changing nature of the trade relations between the EU and Asia since the global financial crisis. The authors evaluate EU trade policy by studying the free trade agreements that it is currently negotiating with Japan, Singapore, and Vietnam. The paper also discusses the issue of granting China market economy status, as well as the impact of the Brexit process. The authors conclude that the EU uses different approaches with each Asian partner, which allows for more flexibility but also prohibits it from entering into a regional agreement with Asia as a whole - as seen in the EUASEAN trade agreement for example.

In his paper, Helble (2017) asks the question of whether and how the TPP can still be salvaged. The recent withdrawal of the US from TPP gives the agreement an uncertain future. Yet the TPP had been recognized as an agreement that substantially updated and extended international trade rules, responding to new technological developments and economic realities. The author argues that some of the achievements of the TPP might not be lost. The TPP offers important lessons for other ambitious regional trade deals, both in terms of process and content. Furthermore, several chapters of the TPP could become blueprints for ongoing and upcoming negotiations at the bilateral, regional, or multilateral level.

The years following the GFEC have also been an era of unprecedented monetary policy. In an effort to stimulate demand, interest rates set by many central banks in developed countries reached negative levels. In their contribution, Angrick and Nemoto (2017) provide an overview of the operational implementation of negative interest rates in Europe and Japan. The authors find substantial heterogeneity in the purpose, design, and operational specificities of negative interest rate policies across economies, with significant consequences for effective market rates, private sector funding conditions, and expectations. Looking at the transmission channels of negative rates, as well as the benefits and risks of the policy, the authors warn of potential adverse effects due to the combination of negative interest rates and tighter liquidity - as well as to capital standards adopted amid the GFC.

Schnabl (2017) studies in his paper the economic effects of loose monetary policy. He argues that a global decline in interest rates led to overinvestment in Japan, Southeast Asia, and China. As for the euro area, a single monetary policy with the European Monetary Union did not shield its member countries from idiosyncratic shocks - mainly due to their diverging fiscal policies. The author concludes that the current expansionary monetary policy thus impedes financial and economic restructuring. He therefore recommends a timely exit from expansionary monetary policy, both in Europe and Asia. 
The last two papers of this special issue are dedicated to questions of development finance and financial stability. The GFEC clearly demonstrated that financial stability can still be threatened by macroeconomic shocks. The paper by Morgan and Zhang (2017) attempts to address one important issue concerning financial stability, namely the relationship between it and mortgage lending. Exploiting a dataset covering 1889 banks in 65 advanced and emerging economies for the period 1987-2014, the authors estimate the effect that the share of mortgage lending by individual banks had on financial stability. The authors find evidence that an increased share of mortgage lending is positive for financial stability for levels between 49 and $68 \%$. For higher levels of mortgage lending shares, however, the impact on financial stability turns negative. Also, the occurrence of a banking crisis reduces the diversification benefits associated with mortgage lending.

Schüller and Wogart (2017) focus in their paper on the emergence of post-crises regional financial institutions in Asia and how European countries have supported this development. Unable to initiate major governance reforms of the existing multinational finance institutions, Asian countries have instead not only set up regional support liquidity arrangements but also their own multilateral development banks. While the US and to some extent Japan have tried to prevent a rebalancing of power within the global financial system, European countries have actively supported these changesmost notably by becoming founding members of the China-led Asian Infrastructure Investment Bank. While these developments will not lead to a new world order when it comes to international finance, emerging market economies and development countries in Asia have nonetheless most certainly been able to gain a greater voice therein.

\section{References}

Angrick S, Nemoto N (2017) Central banking below zero: the implementation of negative interest rates in Europe and Japan. Asia Eur J. https://doi.org/10.1007/s10308-017-0492-3

Bungenberg M, Hazarika A (2017) The european union's trade and investment policy in Asia: new challenges and opportunities in a changing global environment - following individual roadmaps. Asia Eur J. https://oi.org/10.1007/s10308-017-0485-2

Dreger C (2017) Long-term growth perspectives in Japan and the Euro area. Asia Eur J. https://doi. org/10.1007/s10308-017-0486-1

Helble M (2017) Salvaging the trans-pacific partnership: building blocks for regional and multilateral trade opening? Asia Eur J. https://doi.org/10.1007/s10308-017-0487-0

Morgan PJ, Zhang Y (2017) Mortgage lending, banking crises, and financial stability in Asia and Europe. Asia Eur J. https://doi.org/10.1007/s10308-017-0489-y

Schnabl G (2017) Monetary policy and overinvestment in East Asia and Europe. Asia Eur J. https://doi. org/10.1007/s10308-017-0490-5

Schüller M, Wogart JP (2017) The emergence of post-crisis regional financial institutions in Asia with a little help from Europe. Asia Eur J. https://doi.org/10.1007/s10308-017-0491-4 